\title{
High school language division students' perceptions of English as a Lingua Franca
}

\author{
${ }^{\mathrm{a} Z e y n e p ~ Y u ̈ c e d a g ̆ ~}(\mathrm{D})$ and ${ }^{\mathrm{b}}$ Ali Karakaş \\ a Graduate Student, Burdur Mehmet Akif University, Burdur, Turkey, xeyneopu85@gmail.com \\ b Assist. Prof. Dr., Burdur Mehmet Akif University, Burdur, Turkey, akarakas@mehmetakif.edu.tr
}

To cite this article: Yucedağ, Z., \& Karakaş, A. (2019). High school language division students' perceptions of English as a Lingua Franca. Focus on ELT Journal (FELT), 1(1), 27-42. https://doi.org/10.14744/felt.2019.00003

\begin{abstract}
This study aims to discover the perceptions of high school language division students towards English as a lingua franca in a Turkish province. For this purpose, a descriptive survey method was chosen via using a questionnaire consisting of 13 questions. The responses were rated on a 4-point Likert scale. The data were gathered from 85 students of three high schools in the fall term of the 2018/19 school year. Being analysed descriptively, the data revealed that most students believed in the importance of teachers' teaching standard English pronunciation to students and that language teachers should teach good grammar to their students. In spite of the students' strong-willed attitude towards pronunciation, they reported that their teachers seemed to have a higher expectation of their performance in grammar. The results also showcased that language division students desired their teachers to attach much importance to both pronunciation and grammar. Furthermore, as far as gender is concerned, more females than males perceived that native English speaking teachers (NESTs) are more effective teachers for language students, suggesting that government hire NESTs to teach English in Turkey. In conclusion, the findings suggest that the students strongly cling to normative perceptions about English as if it was still the language spoken primarily by native English speakers.
\end{abstract}

Keywords:

English as a lingua franca native English speakers non-native English speakers ownership of English standard language ideology

\section{Introduction}

In recent years, English has gained true value in the globalizing world as an international language used as a means of communication mostly among non-native English speakers (NNESs). After World War II, English has started to transform into a lingua franca throughout the world. It has become a necessity for nations to learn the world language of 'English' in addition to their own languages (Kesgin \& Arslan, 2015). When the growth of English as a global lingua franca is considered, how swiftly English has encroached into educational systems worldwide is evidently seen. Thus, most countries have introduced educational policies, aimed at offering English as a second or foreign language as part of their national curricula (Gómez \& Pérez, 2015).

The status of English as a lingua franca in most communication situations requires reconsidering the teaching of English as a foreign language from different perspectives due 
to the far-reaching consequences of globalization on the speaker profile and divergent uses of English. So, against this backdrop, language teachers are supposed to help their students improve their linguistic skills in a way in which they can cope with several kinds of familiar and unfamiliar accents and render themselves comprehensible to others. Besides, they should be cognizant of the speakers of English from other countries and learn to use it for communication not only in locations where English is used as a native language but also all around the world with speakers from different races and cultures (Mansfield \& Poppi, 2012). Not surprisingly, albeit English spreading as a lingua franca, many learners still aim at reaching the level of inner circle speakers' pronunciation and tend to favour teachers on the basis of their holding a NES or NNES status (Buckingham, 2014). A review of literature shows examination of these issues by language researchers from diverse geographical settings, who roughly observed similar tendencies among learners of English, with a strong desire for NESs as their role models for language use and a strong wish for their pronunciation and accent to be like those of NESs (e.g., Barrett, 2009; Dweik \& Al-Barghouthi 2014; Karakaş et al., 2016; Pilus, 2013; Walkinshaw \& Oanh, 2014). Even worse, in some studies, students were aware of the fact that the majority of their future interlocutors would be NNESs, and most students were pleased with the way they sounded while using English, yet still they insisted on the idea that standard or native English pronunciation should be taught at schools since they could give up on setting NES accents and pronunciation as the ultimate goal of speaking (e.g. Coşkun, 2011; Pilus, 2013). Indeed, such orientations to English among learners go against English as a Lingua Franca (ELF) tenets as it does not favour any speaker over the others in communication. Rather, it gives increased value to communicative effectiveness in interaction and the ways in which speakers meet their linguistic needs in their own terms by implementing different communicative strategies.

It is widely known that the majority of English language teachers do not come from a native English background. They are mostly NNES, who learned English during different stages of their lives, such as in childhood and adulthood, and in different settings, e.g. formal, academic settings, informal immersion with NESs (Dweik \& Al-Barghouthi, 2014). As NNESs currently outdo NESSs in number, ELF interactions most frequently occur among NNESs (De Meerleer, 2012). The increase in the number of NNESs, and their changing lingua-cultural needs because of largely having contacts with NNESs and the transference of ownership of English to any users of it regardless of the users' firstlanguage backgrounds have driven researchers to consider the implications of ELF in language teaching classrooms (Coskun, 2011). Since its birth as a field of research, ELF has greatly influenced the field of language learning and teaching, especially when it comes to speaking and listening skills as well as pronunciation (Calvo-Benzies, 2017).

One major setback in teaching English worldwide is that there seems to be little time allocated for teaching speaking for real-world communication in classrooms when compared with other elements of the language system, such as reading, grammar and vocabulary. Even, previous research provides evidence for this conclusion, as students 
were found to value learning grammar more than learning productive skills (e.g. Shahzadi \& Janjua, 2016; Umo-Udofia \& Andera, 2018). For instance, to clarify what lies behind the favorable attitudes towards grammatical competence among students in certain contexts, researchers argue that most students are into learning the rules of grammar since learning grammar is viewed as crucial and basic not only to communicate effectively in English but also to improve language proficiency (Shazadi \& Janjua, 2016). Moreover, in many settings like Pakistan and Turkey, students are more interested to learn grammar deductively than inductively as it is the way they got used to while learning English starting from the onset of their language learning trajectory.

Pronunciation often loses ground as something unneeded to pass major language exams (Waniek-Klimczak, 2015). Since speaking is such an important aspect of communication, most scholars and even laymen would concede that good second language (L2) learners should not ignore pronunciation. Rightly or wrongly, people often judge a speaker's level of language competence by his/her pronunciation in terms of fluency and accuracy. In this respect, creating a positive first impression on one's interlocutors really counts, particularly in the professional world (Almaqrn \& Alshabeb, 2017). In spite of the socalled emphasis on speaking in policy documents and classroom materials, it has been ignored in schools and universities because of various reasons, yet mostly due to the exaggerated feelings of grammar and vocabulary being of significant value in language teaching practices (Leong \& Ahmadi, 2017).

English pronunciation is seen as one of the most difficult skills to be acquired and improved. This may be owing to factors, such as the irregular correspondence between spelling and pronunciation and the impact factors, such as age, motivation and amount of exposure to the target language on the learning process (Calvo-Benzies, 2013). It is widely assumed that in order to master a second language, it is necessary to know and apply the correct grammatical rules used in any particular language, even if nobody observes such rules while using their own mother tongue in real-life communication (Shahzadi \& Janjua, 2016).

Affective factors like attitudes, orientations, motivation and anxiety which are seen among the different factors influence language learning outstandingly. The attitudes of the learners towards language learning are seen as one of the crucial factors in stimulating the learners to learn the language (Soleimani \& Hanafi, 2013). As attitudes of the learners influencing the learning process may not be explicit, the shareholders of education perhaps ignore the potential effects of such factors on learners' perceptions about language, its use and their own learning experiences. Hence, learners' engagement with the learning process can take different forms depending on how they feel about and perceive it. Hence, the display of their attitudes towards the language negatively or positively can influence the amount of struggle one has to cope with (Umo-Udofia \& Andera, 2018). Learners' attitude plays a vital role in maximizing learning and teaching output. Learners' attitude can be defined as a collection of feelings regarding language use and its status in society (Crystal, 2008). The 
perceptions which are good, bad and neutral may develop or prevent the learning process effectively (Ahmed, 2015). However, it should also be noted that language learning is affected by both attitudes and motivation, since learners with a negative attitude are unlikely to produce satisfactory results (Almaqrn \& Alshabeb, 2017). There is no denying the fact that teachers who take an important role in developing students' language skills in foreign language classrooms are often the first agent in forming how students view language-related constructs, such as grammar and speech patterns, in the target language. Thus, they may either motivate their students towards learning languages by providing a suitable classroom environment or discourage them through their manners and practices that ore out-dated and of no use anymore (Mat \& Soon, 2010).

English is a prestigious foreign language in many countries, including Turkey. Although it is not an official language in Turkey policy-wise, it is the most widely taught foreign language in the education system. Actually, English language has a crucial role in Turkey and is considered to be the most important and functional language for the technological and scientific development of the country (Cetinkaya, 2009). It is a compulsory school subject that students begin to learn from the $2^{\text {nd }}$ grade and continue to learn preferably even after they graduate from the university. The extant research into attitudes towards English in Turkey indicates how welcome English is by students, teachers and even parents in schools (e.g. Karahan, 2007; Şentürk, 2019; Nilay, 2018). However, ELF awareness does not seem to have reached a satisfactory level in Turkey as researchers have observed that the majority of students and teachers cannot still adopt ELF principles in practice wholeheartedly due to some perceived constraints, including primarily assessment and measurement (e.g. Bayyurt et al., 2019; Jenkins, Cogo \& Dewey, 2011; İnceçay \& Akyel, 2014; Griffiths \& Soruç, 2019; Kanık, 2013).

Considering the increasing need and ceaseless interest in learning English as an additional language, the main objective of the current study is to explore the attitudes of language division students towards English at three high schools in a small province. Investigation of language division students' attitudes is salient in that these students mostly prefer language-related programs when they are placed into universities and most of them wish to be language teachers. In a sense, they constitute the antecedents of pre-service teachers group. As their beliefs, opinions and feelings mostly take forms when they are still students, examination of their attitudes towards ELF can enable them to reflect on the current issues around English, and consequently inform their practices and broaden their views as regards the current face of English. Thus, the present study is expected to contribute to the field of English language teaching and learning in Turkey via helping language division students to become more aware of hotly debated issues surrounding English, its use and the ways in which it is taught and learned. 


\section{Method}

\section{Research Questions}

In this research, we sought answers to the following research questions:

1. What are high school language division students' perceptions and attitudes about ELF?

2. Are there any differences in their perceptions and attitudes about English as a lingua franca depending on certain variables, i.e. gender, years of study, and schools attended?

\section{Design}

This study, which aimed to explore high school language department students' perceptions of ELF, was in the form of a descriptive survey study. The survey research in this study included closed-ended questionnaires that were designed to elicit specific information from the participants. Through this design, we wished to learn about the population of high school language department students who were rarely treated as respondents in previous studies with respect to the current issues around the contemporary face of English as a global lingua franca by surveying a sample of that population in a small Turkish city. Overall, our ultimate objective was to describe the patterns of perceptions, thoughts and attitudes among a group of language department students as regards the current role of English being a lingua franca and its diverse implications for language use and education.

\section{Sample}

The sample of the study was comprised of 85 language department students studying at three high schools in the province of Burdur at the time of data collection. The number of students from each high school is as follows: Cumhuriyet (47), Burdur USO (23) and Burdur 15 Temmuz Şehitler (15) Anatolian high schools. The reason behind targeting the language department group is that these students are taking intensive English lessons per week and language is the basic purpose for them in terms of their career prospects. Students placed in such language departments often choose English-major programs such as English Language Teacher Education, English Language and Literature, Linguistics, and Philology after taking the centralized university exam. While recruiting the participants, a purposeful sampling method was employed in the study with an eye to reaching the participants who could provide the most pertinent information on the research topic (Cohen, Manion, \& Morrison, 2007; Dörnyei, 2007; Patton, 2002). The criterion for purposive sampling was that only those who were enrolled in language departments at their schools had to take place in the study as the focus of the investigation was specifically on this particular group of students. The participation in the study was on a voluntary basis. In terms of their gender breakdown, a total number of 43 participants were male and the remaining 42 students were female. As for their years of study, 37 students were in the 11 th grade and 48 were in the 12th grade. Their age range was between 17 and 18 . We included the 11th and 12th-year students in our study as high school students are placed 
into discipline-specific departments upon successfully completing the 10th grade in their schools.

\section{Data collection and analysis}

The data were collected by a 4-point Likert scale questionnaire $(1=$ strongly agree, $2=$ agree, $3=$ disagree, and $4=$ strongly disagree) which was originally developed by Liou (2007) to evaluate the attitudes of high school language students and teachers towards English. It was practical for us to choose a 4-point Likert scale in order to encourage the participants to form an opinion on the items without giving them any safe 'neutral' option. The questions were modified when necessary to make it more suitable for the sample. The questionnaire with reliability value .85 consisted of 13 questions. To ensure the content and face validity of the questionnaire, three experts in a language teacher education program were asked to evaluate the questionnaire. Overall, the experts' content validity ratio emerged as $75 \%$. The ratio was increased to $100 \%$ after the items in the questionnaire were reworded and clarified in accordance with the experts' suggestions. The revised statements are given in the appendix in the order in which they appeared in the questionnaire (see Appendix A).

In the questionnaire, the first group of questions (Q1 to $\mathrm{Q} 8)$ was designed to explore language department students' perceptions about and attitude towards language proficiency of different users in different contexts, particularly in relation to the issues of grammar and pronunciation. Question Q9 was developed to determine students' perceptions about integrating Anglo-American culture into English language teaching content. Through questions from Q10 to Q13, we sought to look into students' attitudes towards English proficiency and pedagogical competence in teaching English, and their attitudes towards NS teachers' professional competences.

Seeing as the study adopted a descriptive survey method, the analysis of the data contained an amalgam of descriptive and inferential statistics. With a purpose to limit our generalization to the study group, i.e. high school language students from three different schools, descriptive statistics consisting of frequency analysis and percentages were run. Additionally, inferential statistics such as ANOVA and independent samples T-tests were carried out to find out whether the students' responses show divergence depending on variables like the schools they are based, gender and year of study. For these tests, statistical analyses were performed by means of computer software, i.e. Statistical Package for the Social Sciences (SPSS), version 22.

\section{Results and Discussion}

\section{Perceptions about ELF-related issues}

It emerged from the analysis of the questionnaire data that almost all of the students (99\%) believed that teaching standard pronunciation to students is a crucial teacher task (Q1). In parallel to this response, according to $96 \%$ of the respondents, teaching good grammar to the students is perceived to be among the core tasks of language teachers (Q2). This 
finding slightly differs from what has been previously found in similar studies. For instance, Calvo-Benzies (2013) observed that although Spanish EFL university students generally considered the teaching of pronunciation to be crucial, it was reported that it only plays a minor role in their EFL classes and teaching materials. However, in other studies, such as those of Nowacka (2012), many students stated that pronunciation is very important to them. What is unclear in those studies is whose pronunciation the respondents took as a benchmark in their perceptions. Although this is not explicitly articulated in the studies, it is very likely that by pronunciation, those studies allude to the standard versions of English, predominantly those of British English and American English. Furthermore, Almaqrn and Alshabeb (2017) reported that 52\% of respondents stated that learning vocabulary and grammar was more important than good pronunciation skills. In spite of the students' strong-willed attitude towards pronunciation, most participants had a higher expectation of students' performance in grammar, with $85 \%$ of them expecting students to use English with correct grammar (Q6). In the studies of Shahzadi and Janjua (2016) and Umo-Udofia and Andera (2018), it was discovered that students relatively held positive attitudes towards grammar. The results obtained for Q1, Q2, and Q6 were consistent with those reported by Liou (2007).

Table 1. Students' Perceptions of ELF-related Issues $(n=85)$

\begin{tabular}{|c|c|c|c|c|}
\hline \multirow[b]{2}{*}{ Questionnaire items } & S. A. & Agree & Disagree & S. D. \\
\hline & \multicolumn{4}{|c|}{ Percentage \% } \\
\hline Q1. ELT teachers should teach good pronunciation to students. & 71 & 28 & 1 & - \\
\hline Q2. ELT teachers should teach good grammar to the students. & 58 & 38 & 4 & 1 \\
\hline $\begin{array}{l}\text { Q3. ELT teachers must try to obtain accent-free language } \\
\text { proficiency at all times. }\end{array}$ & 26 & 38 & 33 & 4 \\
\hline $\begin{array}{l}\text { Q4. ELT teachers must try to speak English without grammatical } \\
\text { errors at all times. }\end{array}$ & 21 & 41 & 38 & - \\
\hline Q5. Students' pronunciation should sound like standard English. & 24 & 38 & 27 & 12 \\
\hline Q6. Students should use correct grammar. & 32 & 53 & 14 & 1 \\
\hline Q7. People using English should try to speak accent-free English. & 27 & 46 & 21 & 6 \\
\hline $\begin{array}{l}\text { Q8. People using English should try to avoid grammatical errors. } \\
\text { Q9. If cultural materials are to be integrated into English language }\end{array}$ & 22 & 42 & 29 & 6 \\
\hline $\begin{array}{l}\text { classes, they should focus on the English speaking countries' } \\
\text { cultures. }\end{array}$ & 32 & 34 & 24 & 11 \\
\hline $\begin{array}{l}\text { Q10. ELT teachers should focus more on language knowledge than } \\
\text { on the pedagogy. }\end{array}$ & 20 & 40 & 33 & 7 \\
\hline Q11. NESTs are more effective teachers for language students. & 53 & 26 & 16 & 5 \\
\hline $\begin{array}{l}\text { Q12. The government should hire NESTs from English speaking } \\
\text { countries to teach English in Turkey. }\end{array}$ & 38 & 40 & 15 & 7 \\
\hline $\begin{array}{l}\text { Q13. Bilingual NNES teachers are better models for students to } \\
\text { learn English. }\end{array}$ & 22 & 45 & 26 & 7 \\
\hline
\end{tabular}

Drawing on the results obtained from these items, the students in the study can be said to have prioritized teaching grammar and pronunciation in a normative manner, suggesting that teachers are the primary agents to help students master good English grammar and 
pronunciation. Nevertheless, what is meant by good English and good grammar by the participants is left to the reader. Previous studies on the perceptions of good English by English-major students demonstrated that these terms are often associated with standard English and native-like English of the educated British or American speakers (Karakaş, 2017). The descriptive statistics of each item on the questionnaire is presented in the table above.

A close inspection of items relating to the status of teachers showed that $67 \%$ of the students perceived NES teachers to be more effective than NNES teachers in teaching English (Q11). In accordance with this perception, more than half of the students $(66 \%)$ suggested that the government adopt a policy of hiring NES teachers to teach English in the official schooling system in Turkey (Q12). This finding shows how positive the students are about NES teachers when it comes to teacher preferences for language classes. Additionally, this finding reflects the governmental stance on solutions to the problem of low English proficiency among Turkish people as the Ministry of National Education (MoNE) attempted to introduce a project, entitled Development of Foreign Language Teaching, in 2011 through hiring 40.000 NES teachers to be employed alongside Turkish teachers of English though the project was not put into practice due to its high cost ("40 bin yabanc1 öğretmen" [40 thousands foreign teachers], 2019). In the literature, there are studies that contradict this finding. For example, although Liou (2007) reached similar results to those obtained from the Q11 and Q12 of the current study, she indicated that $84 \%$ of the respondents agreed that local English teachers were better role models in learning English (Q13). When the results of the frequency analysis were considered as a whole, the questions, i.e. Q1, Q2, Q6, Q11 and Q12, are highly supported by the students whereas the remaining questions did get lower support. However, the literature abounds in studies that support our finding which indicates that NES teachers and NNES teachers are perceived to be preferable depending on the perceived advantages they hold over each other. For instance, Barrett (2009) pointed out that second language learners in an American institution of higher education placed higher value on having NES teachers in the areas of speaking skills, pronunciation, accent, and knowledge of target culture, but at the same time, they valued NNES teachers for their sympathy and ability to explain language rules explicitly. Similar results were also obtained in other contexts, with different study groups, e.g. teachers, pre-service teachers, non-English major students, and English-major students (e.g. Karakaş et al., 2016).

\section{Differences in students' perceptions of ELF depending on certain variables}

In order to investigate whether the students' perceptions differ from one another depending on the schools they are based at, we used an analysis of variance (ANOVA; see Appendix B for the test results). The test results showed significant differences in students' perceptions according to their schools at the 0.05 probability level for the questions Q3 and Q9 (see Table 2 below). Accordingly, the students studying at 15 Temmuz High School highly supported the questions Q3, i.e. ELT teachers must try to obtain accent-free 
language proficiency at all times, and Q9, i.e. If cultural materials are to be integrated into English language classes, they should focus on the English speaking countries' cultures. A possible explanation for these differences might be the influence of the English language teacher(s) at 15 Temmuz Anatolian high school who are perhaps good at imitating NES accents in their speaking and integrating elements of target culture in their classes. The modelling principle suggests that students are inclined to imitate the acts of individuals whom they see as role models for themselves. Considering the fact that in language divisions of high schools, the role models are often the language teachers of students, this conclusion seems feasible.

Table 2. The Degree of Difference in Students' Perceptions according to Schools $(n=85)$

\begin{tabular}{llll}
\hline & \multicolumn{3}{l}{ Schools } \\
\cline { 2 - 4 } Questionnaire items & Cum & USO & 15 TEM \\
\hline Q1. ELT teachers should teach good pronunciation to students. & 1.34 & 1.17 & 1.40 \\
Q2. ELT teachers should teach good grammar to the students. & 1.45 & 1.43 & 1.67 \\
Q3. ELT teachers must try to obtain accent-free language proficiency at all & $2.36 \mathrm{a}^{* 1}$ & $1.96 \mathrm{ab}$ & $1.73 \mathrm{~b}$ \\
times. & & 2.13 \\
Q4. ELT teachers must try to speak English without grammatical errors at & 2.09 & 2.35 & 1.93 \\
all times. & 2.38 & 2.26 & 1.80 \\
Q5. Students' pronunciation should sound like standard English. & 1.81 & 1.96 & 2.07 \\
Q6. Students should use correct grammar. & 1.96 & 2.26 \\
Q7. People using English should try to speak accent-free English. & 2.09 & 2.35 & 2.27 \\
Q8. People using English should try to avoid grammatical errors. & $2.35 \mathrm{a}$ & $1.60 \mathrm{~b}$ \\
Q9. If cultural materials are to be integrated into English language classes, & $2.19 \mathrm{a} *$ & 2.3 & 1.93 \\
they should focus on the English speaking countries' cultures. & & 2.13 \\
Q10. ELT teachers should focus more on language knowledge than on the & 2.45 & 1.80 \\
pedagogy. & 1.81 & 1.52 & 1.80 \\
Q11. NESTs are more effective teachers for language students. & 1.85 & 2.13 \\
Q12. The government should hire NESTs from English speaking countries \\
to teach English in Turkey. \\
Q13. Bilingual NNES teachers are better models for students to learn \\
English.
\end{tabular}

${ }^{1}$ : Means within each row followed by the different letter are not significantly equal at $0.05(*)$ and 0.001 $(* * *)$

To be able to identify the impact of gender on students' perceptions, we ran an independent samples T-test, the results of which revealed significant differences at the 0.05 probability for the Q6, Q11 and Q12 (see Table 3 below and Appendix C for the test results). That is, females highly supported Q6, i.e. Student should use correct grammar, Q11, i.e. NESTs are more effective teachers for language students, and Q12, i.e. The government should hire NESTs from English speaking countries to teach English in Turkey.

When it comes to the likely influence of their year of study in their departments, the T-test results showed that the means of 11 th and 12th-grade students were significantly different on some questionnaire items (see Table 3 and Appendix D for the test results). While students at the 12th grade more strongly agreed with Q9, i.e. If cultural materials are to be integrated in English language classes, they should focus on the English speaking countries' cultures, and Q10, i.e. ELT teachers should focus more on language knowledge than on the pedagogy, those at the 11th grade highly supported Q11, i.e. NESTs are more 
effective teachers for language students, and Q12, i.e. the government should hire NESTs from English speaking countries to teach in Turkey.

Table 3. The Degree of Difference in Students' Perceptions according to Gender and Class $(n=85)$

\begin{tabular}{|c|c|c|c|c|}
\hline \multirow[b]{2}{*}{ Questionnaire items } & \multicolumn{2}{|c|}{ Gender } & \multicolumn{2}{|l|}{ Class } \\
\hline & $\mathrm{F}$ & $\mathrm{M}$ & 11th & 12 th \\
\hline Q1. ELT teachers should teach good pronunciation to students. & 1.29 & 1.33 & 1.32 & 1.29 \\
\hline Q2. ELT teachers should teach good grammar to the students. & 1.55 & 1.42 & 1.43 & 1.52 \\
\hline $\begin{array}{l}\text { Q3. ELT teachers must try to obtain accent-free language } \\
\text { proficiency at all times. }\end{array}$ & 2.26 & 2.02 & 1.95 & 2.29 \\
\hline $\begin{array}{l}\text { Q4. ELT teachers must try to speak English without grammatical } \\
\text { errors at all times. }\end{array}$ & 2.12 & 2.21 & 2.19 & 2.15 \\
\hline Q5. Students' pronunciation should sound like standard English. & 2.31 & 2.23 & 2.16 & 2.35 \\
\hline Q6. Students should use correct grammar. & $1.69 *$ & 2.00 & 1.70 & 1.96 \\
\hline Q7. People using English should try to speak accent-free English. & 2.14 & 1.98 & 2.11 & 2.02 \\
\hline $\begin{array}{l}\text { Q8. People using English should try to avoid grammatical errors. } \\
\text { Q9. If cultural materials are to be integrated into English language }\end{array}$ & 2.21 & 2.16 & 2.32 & 2.08 \\
\hline $\begin{array}{l}\text { classes, they should focus on the English speaking countries' } \\
\text { cultures. }\end{array}$ & 2.00 & 2.26 & $2.43^{*}$ & 1.90 \\
\hline $\begin{array}{l}\text { Q10. ELT teachers should focus more on language knowledge than } \\
\text { on the pedagogy. }\end{array}$ & 2.21 & 2.33 & $2.51 *$ & 2.08 \\
\hline Q11. NESTs are more effective teachers for language students. & $1.52 *$ & 1.93 & 1.27 & 2.08 \\
\hline $\begin{array}{l}\text { Q12. The government should hire NESTs from English speaking } \\
\text { countries to teach English in Turkey. }\end{array}$ & $1.71 *$ & 2.12 & $1.65 *$ & 2.12 \\
\hline $\begin{array}{l}\text { Q13. Bilingual NNES teachers are better models for students to } \\
\text { learn English. }\end{array}$ & 2.26 & 2.09 & 2.24 & 2.12 \\
\hline
\end{tabular}

From these results, it is evident that more students in the $11^{\text {th }}$ grade perceived target language cultural artefacts to be valuable assets in language teaching and conceived of linguistic competence to be of top priority for language teachers compared to the students in the $12^{\text {th }}$ grade. However, the main concern of the $12^{\text {th }}$-grade students was with the nationality background of language teachers, with great desire for the recruitment of NESTs in language classes. This finding is at odds with the findings of some previous studies. For example, Ballar and Winke (2017) found that in the minds of students, accentedness does not translate to unacceptability as a teacher. Namely, whether teachers speak English as their mother tongue was not a decisive criterion for these students. Nonetheless, there are plentiful studies that nearly share the same results with those of this study. To illustrate, a research study completed by Calvo-Benzies (2013) indicated that the law students tended to value NES accents more than NNES ones, whereas students of tourism broadly appreciated both NES and NNES accents.

\section{Conclusion}

The main issue under investigation in this study was how a young group of English-major students perceived ELF and its main principles about language and language education. The investigation did not concern itself with whether students knew the term ELF by name. Rather, the focal attention was paid to the matters ELF has dealt with for a long time, such as awareness of ELF paradigm, perceptions about standard English norms, the 
role of culture in language instruction, and accents used regionally and globally in diverse settings. The findings revealed that high school language department students' perceptions and attitudes towards ELF are very norm-oriented, with great appreciation of the aspects of standard and native Englishes (e.g. grammatical accuracy) as well as speakers of inner circle Englishes. We can presume that these students will hold on to these views in their future engagement with English regardless of whether they use it or teach it. Therefore, it is imperative that language teachers in such language-intensive programs at high schools introduce the diversity of English into their classes through various thought-provoking and awareness-raising tasks so that the students can make better-informed decisions about their linguistic acts and set realistic linguistic goals for themselves.

Being one of the rare studies into the perceptions of high school language department students about ELF, this study has some limitations, primarily due to its analytical framework for data collection and sample. We collected the data through quantitative tools, which do not let us explore the issues under investigation in an in-depth fashion, yet allow us to generalise our results to the students sharing similar characteristics with the study sample. Hence, we recommend that researchers study high school language division students' attitudes and perceptions by means of quantitative and qualitative tools. Most importantly, as preliminary research, this study sheds light on the fact that most perceptions and attitudes are shaped through students' early educational experiences with language learning. Keeping this in mind, the stakeholders of language teaching should make efforts to help students become aware of the current sociolinguistic reality of English and its speaker profile, and how they can exploit their linguistic resources to be effective and skilled language users rather than making futile attempts to use English in conformity with certain ways followed by a particular group of speakers, i.e. NESs.

\section{Disclosure Statement}

No potential conflict of interest was reported by the authors.

\section{References}

40 bin yabancı öğretmen geliyor (2019, March). [40 thousand foreign teachers are on the way]. Hürriyet. Retrieved from http://www.hurriyet.com.tr/gundem/40-bin-yabanci-ogretmen-geliyor-17312507.

Ahmed, S., (2015). Attitudes towards English language learning among EFL learners at UMSKAL. Journal of Education and Practice, 6(18), 6-16.

Almaqrn, R.K. \& Alshabeb, A.M. (2017). EFL Learners' attitudes towards the proper pronunciation of English and podcasts as a facilitator of proper pronunciation. Arab World English Journal, 8(1), 208219.

Ballard, L. \& Winke, P. (2017). Students' attitudes towards English teachers' accents: The interplay of accent familiarity, comprehensibility, intelligibility, perceived native speaker status, and acceptability as a teacher. In T. Isaacs, and P. Trofimovich (eds.), Second Language Pronunciation Assessment: Interdisciplinary perspectives (pp. 121-140). Bristol: Multilingual Matters.

Barrett, M., (2009). A preliminary survey of second language learners' attitudes toward native and non-native ESL/EFL Teachers," Hawaii Pacific University TESOL Working Paper Series, 7(1), 50-61.

Bayyurt, Y., Kurt, Y., Öztekin, E., Guerra, L., Cavalheiro, L., \& Pereira, R., (2019). English language teachers' awareness of English as a lingua franca in multilingual and multicultural contexts. Eurasian Journal of Applied Linguistics, 5(2), 185-202. 
Biricik-Deniz, E., Özkan, Y., \& Bayyurt, Y. (2016). English as a Lingua Franca: Reflections on ELF-Related Issues by Pre-Service English Language Teachers in Turkey. The Reading Matrix, 16(2), 144-161.

Buckingham, L. (2014). Attitudes to English teachers' accents in the Gulf. International Journal of Applied Linguistics, 24(1), 50-75, 2014.

Calvo-Benzies, Y.J. (2013). Spanish EFL university students' views on the teaching of pronunciation: a survey-based study. Language Studies Working Papers, 5, 41-49.

Calvo-Benzies, Y.J. (2017). English as a Lingua Franca (ELF) in ESP contexts: Students' attitudes towards non-native speech and analysis of teaching materials. Alicante Journal of English Studies, 30, 27-60.

Çetinkaya, Y.B. (2009). Language of others: EFL students' perception of and attitude towards English. Ç. $\ddot{U}$. Sosyal Bilimler Enstitüsü Dergisi, 18(1), 109-120.

Cohen, L., Manion, L., \& Morrison, K. (2007). Research methods in education (6th ed.). London: Routledge/Falmer.

Coşkun, A. (2011). Future English teachers' attitudes towards EIL pronunciation. Journal of English as an International Language, 6(2), 46-68.

Crystal, D. (2008). A dictionary of linguistics and phonetics, (6th ed). Oxford, UK: Blackwell.

Dörnyei, Z., (2007). Research Methods in Applied Linguistics. Oxford: Oxford University Press.

Dweik, B. \& Al-Barghouthi, E. (2014). Attitudes of Jordanian graduate students towards native and nonnative English language teachers. Journal of Education and Human Development, 3(2), 627-646.

Gómez, E. \& Pérez, S. (2015). Chilean 12th graders' attitudes towards English as a foreign language. Colombian Applied Linguistics Journal, 17(2), 313-324.

Griffiths, C., \& Soruç, A. (2019). Contextual differences regarding students' perceptions of English as a lingua franca according to subject major and nationality. The Journal of Language Teaching and Learning, 9(1), 53-69.

Gürsoy, E., Korkmaz, S. Ç., \& Damar, A. E. (2013). Foreign language teaching within 4+4+4 education system in Turkey: Language teachers' voice. Eurasian Journal of Educational Research, 13(53), 5974.

İnceçay, G., \& Akyel, A. S. (2014). Turkish EFL Teachers' Perceptions of English as a Lingua Franca. Turkish Online Journal of Qualitative Inquiry, 5(1), 1-12.

Jenkins, J., Cogo, A., \& Dewey, M. (2011). Review of developments in research into English as a lingua franca. Language Teaching, 44(3), 281-315.

Kanık, M. (2013). "She like it" but should we standardize ELF?," Kastamonu Eğitim Dergisi, 21(3), 10591070 .

Karahan, F. (2007). Language attitudes of Turkish students towards the English language and its use in Turkish context. Çankaya University Journal of Arts and Sciences, 7, 73-87.

Karakaş, A. (2017). Students' perceptions of "Good English" and the underlying ideologies behind their perceptions. Journal of Language and Linguistic Studies, 13(2), 487-509.

Karakaş, A., Uysal, H., Bilgin, S., \& Bulut, B. (2016). Turkish EFL learners' perceptions of native Englishspeaking teachers and non-native English-speaking teachers in higher education. Novitas-ROYAL (Research on Youth and Language), 10(2), 180-206.

Kesgin, N. \& Arslan, M. (2015). Attitudes of students towards the English language in high schools. Anthropologist, 20(1,2), 297-305.

Leong, L-M. \& Ahmadi, M. (2017). An analysis of factors influencing learners' English speaking skill. International Journal of Research in English Education, 2(1), 34-41.

Liou, Y.-S. (2010). Who Wants EIL? Attitudes towards English as an International Language: A Comparative Study of College Teachers and Students in the Greater Taipei Area. College English: Issues and Trends, 3, 133-157.

Mansfield, G. \& Poppi, F. (2012). The English as a foreign language/lingua franca debate: Sensitising teachers of English as a foreign language towards teaching English as a lingua franca. Profile, 14(1), 159-172.

Mat, A.C. \& Soon, G.Y. (2010). Grammar in the classroom: students' expectations and reality the case of Arabic and Mandarin. Novitas-ROYAL, 4(1), 51-63.

Nilay, A. (2018). Attitudes of state school students towards learning English as a foreign language. Uluslararası Güncel Eğitim Araştırmaları Dergisi, 4(1), 41-51.

Nowacka, M. (2012). Questionnaire-based pronunciation studies: Italian, Spanish and Polish students' views on their English pronunciation. Research in Language, 10, 43-61.

Patton, M. Q. (2002). Qualitative research and evaluation methods (3rd ed.). Thousand Oaks, CA: Sage Publications. 
Pilus, Z. (2013). Exploring ESL learners' attitudes towards English accents. World Applied Sciences Journal, 21, 143-152.

Seidlhofer, B. (2011). Understanding English as a Lingua Franca. Oxford: Oxford University Press

Senturk, B. (2019). Attitudes of Turkish EFL students towards learning English," International Journal of Curriculum and Instruction, 11(1), 247-255.

Shahzadi, A. \& Janjua, F. (2016). Pakistani ESL student's attitude towards English language grammar: A case study of University of Education Lahore. Journal of Literature, Languages and Linguistics, 20, 17-23.

Soleimani, H. \& Hanafi, S. (2013). Iranian medical students' attitudes towards English language learning. International Research Journal of Applied and Basic Sciences, 4(12), 3816-3823.

Umo-Udofia, I. \& Andera, A. (2018). English language learners' attitude on competence in English grammar among selected secondary schools in Kajiado County, Kenya. African Research Journal of Education and Social Sciences, 5(2), 59-65, 2018.

Walkinshaw, I. \& Oanh, D.H. (2014). Native and non-native English language teachers: student perceptions in Vietnam and Japan. SAGE Open, 4(2), 1-9.

Waniek-Klimczak, E. (2015). Correctness in pronunciation instruction: Teachers' and learners' views. Konin Language Studies, 3(1), 75-88.

Widdowson H. G., (1994). The ownership of English. TESOL Quarterly, 28(2), 377-389. 


\section{Appendix A: Questionnaire items}

(Q1) ELT teachers should teach good pronunciation to students.

(Q2) ELT teachers should teach good grammar to the students.

(Q3) ELT teachers must try to obtain accent-free language proficiency at all times.

(Q4) ELT teachers must try to speak English without grammatical errors at all times.

(Q5) Students' pronunciation should sound like Standard English.

(Q6) Students should use correct grammar.

(Q7) People using English should try to speak accent-free English.

(Q8) People using English should try to avoid grammatical errors.

(Q9) If cultural materials are to be integrated into English language classes, they should focus on the English speaking countries' cultures.

(Q10) ELT teachers should focus more on language knowledge than on the pedagogy.

(Q11) NESTs are more effective teachers for language students.

(Q12) The government should hire NESTs from English speaking countries to teach English in Turkey.

(Q13) Bilingual NNES teachers are better models for students to learn English

Appendix B: ANOVA test results

\begin{tabular}{|c|c|c|c|c|c|c|}
\hline \multicolumn{7}{|c|}{ ANOVA } \\
\hline & & Sum of Squares & $\mathrm{df}$ & Mean Square & $\mathrm{F}$ & Sig. \\
\hline \multirow[t]{3}{*}{ Q1 } & Between Groups &, 590 & 2 & ,295 & 1,242 & 294 \\
\hline & Within Groups & 19,458 & 82 & 237 & & \\
\hline & Total & 20,047 & 84 & & & \\
\hline \multirow[t]{3}{*}{ Q2 } & Between Groups & 621 & 2 & ,311 & ,781 & ,461 \\
\hline & Within Groups & 32,603 & 82 & ,398 & & \\
\hline & Total & 33,224 & 84 & & & \\
\hline \multirow[t]{3}{*}{ Q3 } & Between Groups & 5,565 & 2 & 2,782 & 4,168 & ,019 \\
\hline & Within Groups & 54,741 & 82 & ,668 & & \\
\hline & Total & 60,306 & 84 & & & \\
\hline \multirow[t]{3}{*}{ Q4 } & Between Groups & 1,084 & 2 & ,542 & 953 & ,390 \\
\hline & Within Groups & 46,610 & 82 &, 568 & & \\
\hline & Total & 47,694 & 84 & & & \\
\hline \multirow[t]{3}{*}{ Q5 } & Between Groups & 2,302 & 2 & 1,151 & 1,267 & ,287 \\
\hline & Within Groups & 74,474 & 82 & ,908 & & \\
\hline & Total & 76,776 & 84 & & & \\
\hline \multirow[t]{3}{*}{ Q6 } & Between Groups & ,379 & 2 & 189 & ,382 & ,684 \\
\hline & Within Groups & 40,633 & 82 & ,496 & & \\
\hline & Total & 41,012 & 84 & & & \\
\hline \multirow[t]{3}{*}{ Q7 } & Between Groups & 1,423 & 2 & ,711 & ,984 & ,378 \\
\hline & Within Groups & 59,283 & 82 & ,723 & & \\
\hline & Total & 60,706 & 84 & & & \\
\hline \multirow[t]{3}{*}{ Q8 } & Between Groups & 1,178 & 2 & ,589 & 807 & ,449 \\
\hline & Within Groups & 59,810 & 82 &, 729 & & \\
\hline & Total & 60,988 & 84 & & & \\
\hline \multirow[t]{3}{*}{ Q9 } & Between Groups & 5,482 & 2 & 2,741 & 2,954 &, 050 \\
\hline & Within Groups & 76,094 & 82 & ,928 & & \\
\hline & Total & 81,576 & 84 & & & \\
\hline
\end{tabular}




\begin{tabular}{llrrrrr}
\hline Q10 & Between Groups & 3,617 & 2 & 1,809 & 2,507 &, 088 \\
& Within Groups & 59,159 & 82 &, 721 & & \\
& Total & 62,776 & 84 & & & \\
Q11 & Between Groups & 1,361 & 2 &, 680 &, 828 &, 441 \\
& Within Groups & 67,416 & 82 &, 822 & & \\
& Total & 68,776 & 84 & & & \\
Q12 & Between Groups & 1,457 & 2 &, 729 &, 892 &, 414 \\
& Within Groups & 66,966 & 82 &, 817 & & \\
& Total & 68,424 & 84 & & & \\
Q13 & Between Groups & 2,297 & 2 & 1,149 & 1,568 &, 215 \\
& Within Groups & 60,056 & 82 &, 732 & & \\
\hline
\end{tabular}

Appendix C: Independent samples T-test results according to gender

\begin{tabular}{|c|c|c|c|c|c|c|}
\hline & & \multicolumn{2}{|c|}{$\begin{array}{c}\text { Levene's Test for Equality } \\
\text { of Variances }\end{array}$} & \multicolumn{3}{|c|}{ t-test for Equality of Means } \\
\hline & & $\mathrm{F}$ & Sig. & $\mathrm{t}$ & $\mathrm{df}$ & $\begin{array}{l}\text { Sig. }(2- \\
\text { tailed) }\end{array}$ \\
\hline \multirow[t]{2}{*}{$\mathrm{Q} 1$} & Equal variances assumed & ,906 & ,344 &,- 374 & 83 & ,709 \\
\hline & Equal variances not assumed & & &,- 375 & 82,043 & ,709 \\
\hline \multirow[t]{2}{*}{ Q2 } & Equal variances assumed & 2,289 & ,134 & ,945 & 83 & ,347 \\
\hline & Equal variances not assumed & & & ,942 & 77,129 & ,349 \\
\hline \multirow[t]{2}{*}{ Q3 } & Equal variances assumed &, 524 & ,471 & 1,304 & 83 & ,196 \\
\hline & Equal variances not assumed & & & 1,304 & 82,987 & ,196 \\
\hline \multirow[t]{2}{*}{ Q4 } & Equal variances assumed &, 881 &, 351 &,- 550 & 83 &, 584 \\
\hline & Equal variances not assumed & & &,- 549 & 81,249 &, 585 \\
\hline \multirow[t]{2}{*}{ Q5 } & Equal variances assumed & 613 & ,436 & ,369 & 83 & ,713 \\
\hline & Equal variances not assumed & & & ,369 & 82,097 & ,713 \\
\hline \multirow[t]{2}{*}{ Q6 } & Equal variances assumed & ,938 & ,336 & $-2,082$ & 83 & ,040 \\
\hline & Equal variances not assumed & & & $-2,082$ & 82,992 & ,040 \\
\hline \multirow[t]{2}{*}{ Q7 } & Equal variances assumed & 2,140 & ,147 & ,900 & 83 & ,371 \\
\hline & Equal variances not assumed & & & ,898 & 79,678 & ,372 \\
\hline \multirow[t]{2}{*}{ Q8 } & Equal variances assumed & 1,286 & ,260 & 277 & 83 & ,782 \\
\hline & Equal variances not assumed & & & ,276 & 80,213 &, 783 \\
\hline \multirow[t]{2}{*}{ Q9 } & Equal variances assumed &, 081 &, 777 & $-1,200$ & 83 & ,234 \\
\hline & Equal variances not assumed & & & $-1,198$ & 81,557 & ,234 \\
\hline \multirow[t]{2}{*}{ Q10 } & Equal variances assumed & 1,716 & ,194 &,- 591 & 83 &, 556 \\
\hline & Equal variances not assumed & & &,- 590 & 79,136 &, 557 \\
\hline \multirow[t]{2}{*}{ Q11 } & Equal variances assumed & 6,158 & ,015 & $-2,113$ & 83 & ,038 \\
\hline & Equal variances not assumed & & & $-2,122$ & 74,407 & ,037 \\
\hline \multirow[t]{2}{*}{ Q12 } & Equal variances assumed &, 122 &, 728 & $-2,094$ & 83 & ,039 \\
\hline & Equal variances not assumed & & & $-2,097$ & 82,402 & ,039 \\
\hline \multirow[t]{2}{*}{ Q13 } & Equal variances assumed & 3,525 & ,064 & ,903 & 83 & ,369 \\
\hline & Equal variances not assumed & & & 901 & 81,389 &, 370 \\
\hline
\end{tabular}


Appendix D: Independent samples T-test results according to the years of study

\begin{tabular}{|c|c|c|c|c|c|c|}
\hline & & \multicolumn{2}{|c|}{$\begin{array}{c}\text { Levene's Test for Equality } \\
\text { of Variances }\end{array}$} & \multicolumn{3}{|c|}{ t-test for Equality of Means } \\
\hline & & $\mathrm{F}$ & Sig. & $\mathrm{t}$ & $\mathrm{df}$ & $\begin{array}{l}\text { Sig. (2- } \\
\text { tailed) }\end{array}$ \\
\hline \multirow[t]{2}{*}{$\mathrm{Q} 1$} & Equal variances assumed & ,068 & ,794 & ,304 & 83 & ,762 \\
\hline & Equal variances not assumed & & & 306 & 79,648 & ,760 \\
\hline \multirow[t]{2}{*}{ Q2 } & Equal variances assumed & 1,312 & 255 &,- 640 & 83 &, 524 \\
\hline & Equal variances not assumed & & &,- 658 & 82,757 &, 513 \\
\hline \multirow[t]{2}{*}{ Q3 } & Equal variances assumed & ,262 & 610 & $-1,894$ & 83 & 062 \\
\hline & Equal variances not assumed & & & $-1,904$ & 79,084 & 061 \\
\hline \multirow[t]{2}{*}{ Q4 } & Equal variances assumed & ,090 & ,764 & ,262 & 83 & ,794 \\
\hline & Equal variances not assumed & & & 263 & 79,112 & ,793 \\
\hline \multirow[t]{2}{*}{ Q5 } & Equal variances assumed & 15,041 &, 000 &,- 917 & 83 & 362 \\
\hline & Equal variances not assumed & & &,- 966 & 81,262 & 337 \\
\hline \multirow[t]{2}{*}{ Q6 } & Equal variances assumed & ,017 & 896 & $-1,691$ & 83 & ,095 \\
\hline & Equal variances not assumed & & & $-1,708$ & 80,164 & 092 \\
\hline \multirow[t]{2}{*}{ Q7 } & Equal variances assumed & ,036 &, 850 & ,467 & 83 & ,642 \\
\hline & Equal variances not assumed & & & ,469 & 78,444 & 641 \\
\hline \multirow[t]{2}{*}{ Q8 } & Equal variances assumed & 4,137 &, 045 & 1,298 & 83 & , 198 \\
\hline & Equal variances not assumed & & & 1,359 & 82,190 & ,178 \\
\hline \multirow[t]{2}{*}{ Q9 } & Equal variances assumed & ,766 & ,384 & 2,571 & 83 & ,012 \\
\hline & Equal variances not assumed & & & 2,550 & 75,072 & 013 \\
\hline \multirow[t]{2}{*}{ Q10 } & Equal variances assumed & 4,295 & 041 & 2,334 & 83 &, 022 \\
\hline & Equal variances not assumed & & & 2,276 & 69,031 & 026 \\
\hline \multirow[t]{2}{*}{ Q11 } & Equal variances assumed & 17,078 &, 000 & $-4,567$ & 83 &, 000 \\
\hline & Equal variances not assumed & & & $-4,928$ & 73,580 &, 000 \\
\hline \multirow[t]{2}{*}{ Q12 } & Equal variances assumed & 6,472 & 013 & $-2,486$ & 83 &, 015 \\
\hline & Equal variances not assumed & & & $-2,611$ & 81,678 &, 011 \\
\hline \multirow[t]{2}{*}{ Q13 } & Equal variances assumed & ,419 &, 519 & 625 & 83 & ,534 \\
\hline & Equal variances not assumed & & & .636 & 81,708 &, 526 \\
\hline
\end{tabular}

\section{Copyrights}

Copyright for this article is retained by the author(s), with first publication rights granted to the Journal.

This is an open-access article distributed under the terms and conditions of the Creative Commons Attribution license (CC BY-NC-ND) (http://creativecommons.org/licenses/by-nc-nd/4.0/). 